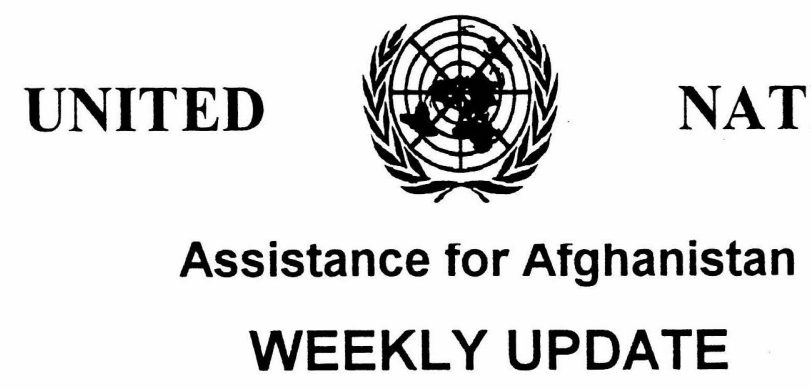

Issue No.314

25 May 1999

\section{Mazar Mission}

A mission of international staff of UNICEF, UNHCR, WFP, Habitat, FAO and the Office of UN Coordinator for Afghanistan visited Mazar from $17^{\text {th }}$ to $19^{\text {th }}$ May. This was the first mission of $\mathrm{UN}$ international staff since the UN's evacuation of the area in autumn 1997. Warmly welcomed by local authorities, the mission noted that the security situation in Mazar continues to be quiet.

UNICEF stated that EPI activities in Mazar and two other northern provinces will resume on a step by step basis now that cold chain facilities are back in place. UNICEF's initiatives in the health and water sectors will also gradually resume.

Informal observation indicates that the situation is harder for the most vulnerable in Mazar. Household assets are continuing to be sold in the market place; this activity appears to have increased since 1997. Begging is also on the rise. Although wheat prices are low, preliminary indications are that many households are finding it difficult to buy enough. An increase in available labourers has resulted in a decrease in labour wages.

In general, commercial activity is reduced compared to previously. No movement of goods was observed across the Uzbekistan border either by barge on the river or across the bridge. This border is officially closed but in the past the Uzbek authorities had accorded permission to the UN for commodity movement. Trucks car- rying goods from Iran and Turkmenistan were observed in the market.

FAO's preliminary indications are that this year's harvest may be significantly below what was expected because of drought. This may lead to price increases in the area. However, the upcoming crop assessment mission will offer more information on crop production prospects.

\section{Central Highlands}

The first convoy carrying $600 \mathrm{MT}$ of wheat left Kabul on $20^{\text {th }}$ May enroute for Panjao and the beginning of the second phase of WFP 1999 Hazarajat emergency food distribution. The WFP team of four national staff monitoring the distribution left Kabul at the same time. The distribution, which is being conducted in collaboration with OXFAM, started on $24^{\text {th }}$ May. A second convoy, also of $600 \mathrm{MT}$, is scheduled to leave Kabul for Waras district of Bamyan Province in a week's time.

WFP has conducted a series of emergency food distributions, in winter 1997, spring 1998, and December-January 1999. In this phase of the operation, WFP will send in 1800 tons of food for over 70,000 people. WFP is targeting the poorest of the poor, the landless, female-headed households and the displaced.

A distribution in the provinces of Uruzgan (Sharistan and Daikundi) and Wardak (Behsud I and II) is planned for June. 


\section{Food Security}

The WFP food security baseline study for Jalalabad is complete. The most vulnerable families are those without a male wage earner. Without assistance, they earn only $70 \%$ of the minimum cash income required (which includes food and non-food items). Therefore, they cannot afford to buy such essentials as clothing and fuel. Households with only one man, working in casual labour or government employment, were the next most vulnerable group. While they can cover their minimum food needs, they can meet only around $85 \%$ of their minimum income needs.

Under these circumstances, WFP food mainly makes up for lack of income, and allows poor households to achieve minimum income needs. Begging and sale of assets are less visible than in Kabul and Mazar, and the poorest people have a more varied diet than the poorest in Kabul and Mazar.

However, WFP notes that there has been a worrying decrease in terms of trade between wheat flour and labour between 1998 and 1999. This was first apparent in April and continues into May. In 1998, one day's work bought $8.3 \mathrm{~kg}$ of wheat. Now it buys $5.0 \mathrm{~kg}$.

\section{Health/Education}

\section{Immunisation}

Now that the first round of National Immunisation Days (NIDs) has been completed successfully, UNICEF and WHO in collaboration with $\mathrm{MoPH}$ and health NGOs are reviewing the first round and preparing for the second round.
WHO in cooperation with $\mathrm{MoPH}$ organized the first Technical Coordination Committee meeting on $17^{\text {th }}$ May at the Ministry of Public Health. Mr. Mohammad Abbas Akhund, Minister of Public Health chaired the meeting. He expressed his appreciation for UNICEF, WHO and health NGOs. Issues discussed included reviewing reports on the first round of NIDs, update of ORT/HES campaign and MoPH, UNICEF, WHO, and PHC workshops in Laghman.

In Badakhshan Province, the Office of the Coordinator organised a monthly meeting on $18^{\text {th }}$ May. Participants from UN agencies and NGOs discussed ways to improve coordinating of their activities in the province.

\section{Medical Supplies}

WHO Representative Dr. M.A. Jama during his recent mission to Kabul visited the Kabul Medical Institute. He donated medical equipment to the institute.

WHO distributed medical supplies for $\mathrm{MCH}$ clinics in Kandahar. WHO also provided bicycles for AFP(Acute Flaccid Paralysis) focal points to facilitate the monitoring and reporting activities for polio eradication in Afghanistan.

WHO also distributed medical supplies in Ghazni, Jalalabad, Badakhshan, Herat, Farah, Kunduz, and Baghlan.

\section{Disability Training}

\section{Orphans on the Job}

CDAP completed a six-month vocational training project for orphans in Kandahar. The project, run by RAPSA (a local NGO), trained 40 most needy orphans, who are the 
only breadwinners of their families, in tailoring and maintenance of electronics. All the trainees were awarded with certificates and provided with toolkits. Most of them took up jobs in the local market immediately after their graduation. Representatives of the local authorities, heads of planning and education departments, ARRP/UNOPS, WFP, CDAP/UNOPS and SWABAC attended the graduation ceremony.

\section{Reconstruction and Rehabilitation}

Assessment of Nahr-e-Shahi canal headwork carried out in collaboration with UNOPS was completed.

In Farah Province, the community forums published their first newsletter, named "Parmakhtag" as a tool for dissemination of information.

\section{Agriculture}

\section{Livestock}

FAO distributed 10,000 doses of Anthrax vaccine to Arghandab Veterinary Field Units.

\section{Crops}

FAO monitored integrated production and production field activities of district trainers in Paktia, Paktika and Khost. FAO also held meetings with the trainers regarding better implementation of the IPP programme. FAO also monitored demonstration orchards in Ander District of Ghazni Province, visited local farmer orchards and provided technical advice management to the field staff.

In Farah Province, FAO planted 800 square metres of onion seedlings in Shin- dand District and collected broccoli and radish seed.

Summer crop seed processing continued in Kabul and Kunar.

\section{Mine Action Programme}

180 newly returned families have been trained by mine awareness teams in Musahi, Logar Province.

\section{Narcotics}

UNDCP in conjunction with the authorities has planned to celebrate the UN Drug Day in Kabul, Kandahar, and Jalalabad and Afghan Refugee Camps in Peshawar on $26^{\text {th }}$ June.

The celebration is intended to support the UN's efforts for the elimination of illicit drug production, trafficking, and drug abuse in Afghanistan. The occasion will help in enhancing drug awareness in the Afghan community to extend their cooperation for UN drug control efforts. It will also demonstrate to Afghans that opium poppy production will increase the number of drug abusers in the country.

Activities such as volleyball, traditional games, poetry, Hussni Qira't, and dramas have been planned for both male and female participants on the day. 


\section{Assistance for Afghanistan WEEKLY UPDATE}

Issue No. $314 \quad 25$ May 1999

\section{Mazar Mission}

A mission of international staff of UNICEF, UNHCR, WFP, Habitat, FAO and the Office of UN Co-ordinator for Afghanistan visited Mazar from 17th to 19th May. This was the first mission of UN international staff since the UN's evacuation of the area in autumn 1997. Warmly welcomed by local authorities, the mission noted that the security situation in Mazar continues to be quiet. UNICEF stated that EPI activitics in Mazar and two other northern provinces will re-sume on a step by step basis now that cold chain facilities are back in place.

UNICEF's initiatives in the health and water sectors will also gradually resume. Informal observation indicates that the situation is harder for the most vulnerable in Mazar. Household assets are continuing to be sold in the market place; this activity appears to have increased since 1997. Begging is also on the rise. Although wheat prices are low, preliminary indications are that many households are finding it difficult to buy enough. An increase in available labourers has resulted in a decrease in labour wages. In general, commercial activity is reduced compared to previously. No movement of goods was observed across the Uzbekistan border either by barge on the river or across the bridge. This border is officially closed but in the past the Uzbek authorities had accorded per-mission to the UN for commodity movement. Trucks carrying goods from Iran and

Turkmeni-stan were observed in the market. FAO's preliminary indications are that this year's harvest may be significantly below what was expected because of drought. This may lead to price increases in the area. However, the upcoming crop assessment mission will offer more information on crop production prospects.

\section{Central Highlands}

The first convoy carrying $600 \mathrm{MT}$ of wheat left Kabul on 20th May enroute for Panjao and the beginning of the second phase of WFP 1999 Hazarajat emergency food distribution. The WFP team of four national staff monitoring the distribution left Kabul at the same time. The distribution, which is being conducted in collaboration with OXFAM, started on 24th May. A second convoy, also of $600 \mathrm{MT}$, is scheduled to leave Kabul for Waras district of Bamyan Province in a week's time.

WFP has conducted a series of emergency food distributions, in winter 1997, spring 1998, and December-January 1999. In this phase of the operation, WFP will send in 1800 tons of food for over 70,000 people.

WFP is targeting the poorest of the poor, the landless, female-headed households and the displaced. A distribution in the provinces of Uruzgan (Sharistan and Daikundi) and Wardak (Behsud I and II) is planned for June.

\section{Food Security}

The WFP food security baseline study for Jalalabad is complete. The most vulnerable families are those without a male wage earner.

Without assistance, they earn only $70 \%$ of the minimum cash income required (which includes food and non-food items). Therefore, they cannot afford to buy such essentials as clothing and fuel 
Households with only one man, working in casual labour or government employment, were the next most vulnerable group. While they can cover their minimum food needs, they can mect only around $85 \%$ of their minimum income needs. Under these circumstances, WFP food mainly makes up for lack of income, and allows poor households to achieve minimum income needs. Begging and sale of assets are less visible than in Kabul and Mazar, and the poorest people have a more varied diet than the poorest in Kabul and Mazar. However, WFP notes that there has been a worrying decrease in terms of trade between wheat flour and labour between 1998 and 1999. This was first apparent in April and continues into May. In 1998, one day's work bought $8.3 \mathrm{~kg}$ of wheat. Now it buys $5.0 \mathrm{~kg}$.

\section{Health/Education}

\section{Immunisation}

Now that the first round of National Immunisation Days (NIDs) has been completed successfully, UNICEF and WHO in collaboration with MoPH and health NGOs are reviewing the first round and preparing for the second round. WHO in co-operation with $\mathrm{MoPH}$ organised the first Technical Co-ordination Committee meeting on 17th May at the Ministry of Public Health. Mr. Mohammad Abbas Akhund, Minister of Public Health chaired the meeting. He expressed his appreciation for UNICEF, WHO and health NGOs. Issues discussed included reviewing reports on the first round of NIDs, update of ORT/HES campaign and MoPH, UNICEF, WHO, and PHC workshops in Laghman. In Badakhshan Province, the Office of the Co-ordinator organised a monthly meeting on 18th May. Participants from UN agencies and NGOs discussed ways to improve co-ordinating of their activities in the province.

\section{Medical Supplies}

WHO Representative Dr. M.A. Jama during his recent mission to Kabul visited the Kabul Medical Institute. He donated medical equipment to the institute. WHO distributed medical supplies for MCH clinics in Kandahar. WHO also provided bicycles for AFP(Acute Flaccid Paralysis) focal points to facilitate the monitoring and reporting activities for polio eradication in Afghanistan. WHO also distributed medical supplies in Ghazni, Jalalabad, Badakhshan, Herat, Farah, Kunduz, and Baghlan.

\section{Disability Training}

Orphans on the Job

CDAP completed a six-month vocational training project for orphans in Kandahar. The project, run by RAPSA (a local NGO), trained 40 most needy orphans, who are the only breadwinners of their families, in tailoring and maintenance of electronics. All the trainees were awarded with certificates and provided with tool-kits. Most of them took up jobs in the local market immediately after their graduation. Representatives of the local authorities, heads of planning and education departments, ARRP/UNOPS, WFP, CDAP/UNOPS and SWABAC attended the graduation ceremony.

\section{Reconstruction and Rehabilitation}

Assessment of Nahr-e-Shahi canal headwork carried out in collaboration with UNOPS was completed. In Farah Province, the community forums published their first newsletter, named "Parmakhtag" as a tool for dissemination of information.

\section{Agriculture}




\section{Crops}

FAO monitored integrated production and production ficld activities of district trainers in Pak-tia, Paktika and Khost. FAO also held meetings with the trainers regarding better implementation of the IPP programme. FAO also monitored demonstration orchards in Ander District of Ghazni Province, visited local farmer orchards and provided technical advice management to the field staff. In Farah Province, FAO planted 800 square metres of onion seedlings in Shindand District and collected broccoli and radish seed. Summer crop seed processing continued in Kabul and Kunar.

\section{Mine Action Programme}

180 newly returned families have been trained by mine awareness teams in Musahi, Logar Province.

\section{Narcotics}

UNDCP in conjunction with the authorities has planned to celebrate the UN Drug Day in Kabul, Kandahar, and Jalalabad and Afghan Refugee Camps in Peshawar on 26th June. The celebration is intended to support the UN's efforts for the elimination of illicit drug production, trafficking, and drug abuse in Afghanistan. The occasion will help in enhancing drug awareness in the Afghan community to extend their co-operation for $\mathrm{UN}$ drug control efforts. It will also demonstrate to Afghans that opium poppy production will increase the number of drug abusers in the country. Activities such as volleyball, traditional games, poetry, Hussni Qira't, and dramas have been planned for both male and female participants on the day.

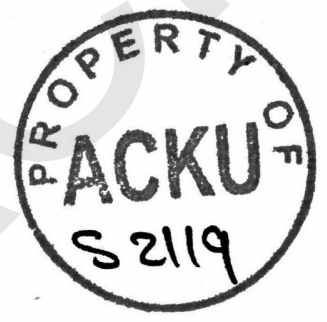

